\title{
Social Learning Tools for Environmentally Sustainable Consumption Behavior in Primary Schools
}

\author{
Meenakshi Sharma ${ }^{1}$ and Dr. Leela Rani ${ }^{2}$
}

\begin{abstract}
UN's Millennium Development Goals declared in 2010 stated sustainable consumption's importance in ensuring environmental sustainability. Given the roles education, children and social learning process are expected to play in sustainability, this study aims to identify tools for active \& passive social learning (SL) perceived by teachers (involved in delivering environmental education) as appropriate \& effective for primary school children (chiefly focusing on environmentally sustainable consumption behavior $\{\mathrm{ESCB}\})$. Study's largely exploratory nature with a limited sample from Bhiwadi (India) was aimed at setting framework rather than generalization of results. Apart from interviewing fifty respondents from government and private schools with a semi-structured questionnaire (16 SL tools across 16 ESCBs), SL tools were also identified from text books. Data on was put through qualitative and quantitative analysis. Results showed that patterns in teachers' preferences for SL tools were similar across school types but preferences only partly matched with recommendations from text books and/or research literature. Teachers' qualitative statements for opportunities, constraints and opinions add to study's strength. Findings hold useful implications for sustainability educators who aim to prod and inspire young minds for a sustainable environment. Insights would guide educationists to evolve effective SL tools for classroom experience.
\end{abstract}

\section{Introduction}

"Human activity is putting such strain on the natural foundations of the earth that the ability of the Planet's ecosystems to sustain future generations can no longer be taken for granted" (Glasser,2009). Multiple problems that threaten environment and human life- like: global warming, ozone depletion, water and air pollution, loss of species and farmland erosion stand related to overconsumption of resources (Tanner, 2003; Said, 2003; Steg, 2009) production pattern and other human activity (Said, 2003; Hanss, 2013). Household consumption alone accounts for more than $60 \%$ of all environmental impacts (Park, 2011; Schrader, 2011). UN’s Millennium Development Goals (2010) underlined sustainable consumption as important for environmental sustainability and combating poverty. Sustainable consumption simultaneously optimizes environmental, social, and economic consequences of acquisition, use and disposing off in order to meet the needs of both current and future generations (Phipps, 2013). One way to generate an enduring impact on curtailing and even reversing negative impact of household consumption activities on environment is by social learning (SL) (Glasser, 2009) and as Monroe (2003) suggests, this could have important implications for environmental education. Additionally, Glasser (2009) emphasizes that sustainable development is a lifewide and lifelong endeavor, involving individuals, institutions and societies. Special role 
for children is proposed as formation of attitudes towards environment begins at an early age (Bryant, 1977) and children play an important role in deciding or influencing present and future consumption patterns. To equip children with appropriate skills for making correct choices regarding environmental issues, SL could help gain concepts faster better (Light, 2000; Said, 2007). In this backdrop it makes sense to investigate which SL tools (active and/or passive tools) are perceived to be appropriate by teachers for delivering environmentally sustainable consumption behavior (ESCB) to children. While child's SL covers interactions it's with parents, teacher and peers; current study focuses only their interactions with teachers. This study is expected to give a broad overview of teaching tools perceived to be appropriate and effective for children. It is expected, judicious choice of tools by teachers would lead to better impact on children's understanding about environmental issues and their impact.

\section{Literature Review}

This section gives a brief on sustainable development, then presents meanings and relationship amongst terms that are often used in context of sustainability and/or sustainable development. Later sub-sections extended applications of ESCB to children's context and the role education could play in enhancing desirable ESCBs among children. Last sub-section puts the role of SL learning and its tools (active and passive) for sustainability education.

\subsection{Sustainability, ESCB, Children}

Rising environmental concern made "sustainability" the key issue in the twentieth century at multiple international forums - United Nations Conference on Human Environment, 1972; United Nations World Charter for Nature, 1982; World Commission on Environment and Development, 1992 and later at World Summit on Sustainable Development, Johannesburg, 2002. They were aimed at enhancing awareness and attitudes about environmental issues. Sustainable Development refers to "meeting the needs of current generations without limiting the ability of future generations to meet their own needs" (Burtland Commission, 1987) and focuses mainly on three dimensions of sustainability: economic, social and environmental(Pezzoli, 1997, see figure 1).

Other terms related to environmental sustainability are: pro-environmental behavior, environmentally sustainable behavior, environment friendly behavior and environmentally sustainable consumption behavior; these are often used interchangeably (Thogersen, 2002) and have been defined by overlapping meanings (Kollmuss,2002; Eialm,2012; Eialm,2012;Sawitri, 2015). The one by Sawitri, gives a comprehensive overview:

"Pro-environmental behavior is conscious actions performed by an individual so as to lessen the negative impact of human activities on the environment or and to enhance the quality of the environment. examples of pro-environmental behavior include environmental activism (e.g., active involvement in environmental organizations), nonactivist behavior in the public-sphere (e.g., petitioning on environmental issues), private sphere environmentalism (e.g., saving energy, purchasing recycled goods), and behavior in organizations (e.g., product design)." Scope of this study relates to "private sphere 
environmentalism". For a deeper meaning, we also refereed to Park's (2011) statement for ESCB, which states "ESCB as consumers' purchase, use and disposing-off of personal and household products in ways that preserve environment".

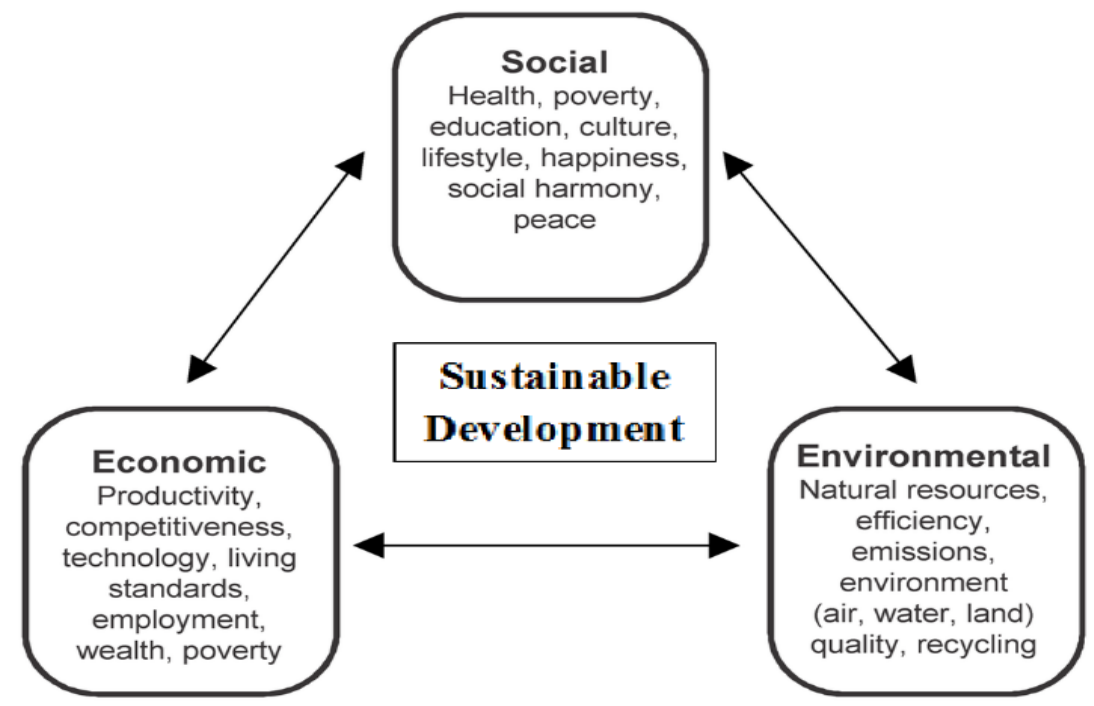

Figure 1: Social, environmental and economic aspects of sustainability, and some of the factors that comprise them.

In identifying the most important sections of society that can closely impact and get impacted by environment sustainability, children get the center stage. Their environmental attitudes are moldable (Bryant, 1977) and they are central to deciding future consumption patterns and choices (see 'Introduction'; Muderrisoglu, 2011). Additionally, the fact that they comprise nearly half of the population in many developing countries (Engdahl, 2010) makes them a powerful stakeholder. Therefore, it becomes important to investigate how children can be sensitized to develop their world view \& connection between them and natural environment. It must be noted that while children's skills for making pro-environment decisions need development (Said, 2007), they have shown such understanding from past several years (Strong, 1998).

\subsection{Role of environmental education in children's ESCB}

Education has been identified as an important tool in promoting sustainable quality lifestyles by equipping people with right type of knowledge, values and skills (Council for Environment Education, 1998). Several researchers (Sudarmadi, 2001; Glasser, 2009) have pointed to the strategic, life-long and life-wide role of education for sustainable lifestyle; others have investigated specific constructs like awareness, concern values, skills, attitudes, commitment and behavior to find out how they are influenced by environmental education. A brief account of few such studies is given in table 1 . The above background was considered as highly supportive of an in-depth investigation to find how educational tools are actually perceived wrt their utility for teaching ESCBs to 
children at school. Choice of classroom setup derived from SL paradigm and is presented in the next section along with how learning comes about.

\subsection{Social Learning and ESCB}

A brief peep into the psychology of young children's learning (Pollard, 1996) reveal that social constructivism(influence of 'culture and interactions with others' on learning) and symbolic interactionist approach (developing a sense of self and identity which later formed the basis to act), both formed important building blocks for understanding how children learn in the social context. This brings to the next foundational concept in our study, namely, social learning (SL).

In his book, 'Social learning- Towards a Sustainable World' Wals(2009) brings together contribution from a wide range of perspectives. One of them by Glasser(chapter 2, pages 35 to 61) first gives ideas and definition by researchers and thinkers regarding SL (page 47-48) and then puts his understanding about SL - "as long as learning by individuals or collectives involves some form of input drawn from others, I characterize it as social learning". He then address the question if SL will lead to sustainability, and mentions that while this cannot be expected to happen automatically, his offer to address tentative set of challenges (page 54) could show the way. One of these challenges "identifying well documented testable SL techniques which help people in understanding their value \& concerns to be able to link them to daily actions \& practices"- formed base of our study. In the same chapter, Glasser puts the two forms of SL namely active and passive, into the context of sustainable development. Brief description of active learning (AL) and passive learning (PL) is given here. While AL is inherently dialogical, built on conscious interaction and communication between at least two living entities and leads to construction of new understanding, attitudes \& thoughts (Bonwell, 1991; Luckner, 1997)'; PL rests on the prior learning/wisdom of others (Wals, 2009, page 50). Table 2 contrasts important characteristics of AL and PL modes (Hartley, 1969; Wilke, 2003; Wales,2007; Michel, 2009; Mahmood,2011).

While effectiveness of AL tools over PL tools was found (Kitzerow, 1990; Kyriacou, 1992; McCarthy, 2000; Omelicheva, 2008; Michel, 2009), some students may really learn better through PL tools because of differences in learning styles (Rodrigues, 2004). Thus while the importance of none of these tools can be negated, it would be desirable to suit choice of teaching tools to context. We aim to summarize teachers' perceptions towards 


\begin{tabular}{|c|c|c|c|c|}
\hline \multicolumn{5}{|c|}{$\begin{array}{l}\text { Table 1: Research studies investigating variables related to pro-environmental } \\
\text { context. }\end{array}$} \\
\hline \multicolumn{5}{|l|}{$\begin{array}{l}\mathrm{A} \\
\&\end{array}$} \\
\hline $\begin{array}{l}\text { Strong } \\
(1998)\end{array}$ & $\begin{array}{l}\text { Primary } \\
\text { school } \\
\text { children, } \\
\text { England }\end{array}$ & $\begin{array}{l}\text { Environmental } \\
\text { knowledge, } \\
\text { awareness }\end{array}$ & - & $\begin{array}{l}\text { Exploratory study, It found that levels } \\
\text { of environmental understanding } \\
\text { amongst children are high. }\end{array}$ \\
\hline $\begin{array}{l}\text { Sudarmadi } \\
(2001)\end{array}$ & $\begin{array}{l}\text { Adults, } \\
\text { Jakarta, } \\
\text { Indonesia }\end{array}$ & $\begin{array}{l}\text { Environmental } \\
\text { awareness, attitude, } \\
\text { knowledge across } \\
\text { two groups: } \\
\text { community group } \\
\text { and educated } \\
\text { group }\end{array}$ & - & $\begin{array}{l}\text { - Environmental awareness, } \\
\text { attitude and knowledge of educated } \\
\text { group were greater than the community } \\
\text { group significantly. } \\
\text { F For awareness it was } \\
\text { significant, and attitude difference was } \\
\text { non-significant. }\end{array}$ \\
\hline $\begin{array}{l}\text { Said } \\
(2003)\end{array}$ & $\begin{array}{l}\text { School } \\
\text { teacher, } \\
\text { Malaysia }\end{array}$ & $\begin{array}{l}\text { Knowledge, } \\
\text { environmental } \\
\text { concern and } \\
\text { ecologically } \\
\text { conscious } \\
\text { consumer behavior }\end{array}$ & - & $\begin{array}{l}\text { - Environmental knowledge } \\
\text { was fair but lacking in general } \\
\text { understanding } \\
\text { - Environmentally responsible } \\
\text { behavior was not in consonance with } \\
\text { level of concern and knowledge. }\end{array}$ \\
\hline $\begin{array}{l}\text { Wong } \\
(2003)\end{array}$ & $\begin{array}{l}\text { University } \\
\text { students, } \\
\text { Beijing } \\
\end{array}$ & $\begin{array}{l}\text { Environmental } \\
\text { Awareness }\end{array}$ & - & $\begin{array}{l}\text { Environmental awareness helps in } \\
\text { increasing environmental activism }\end{array}$ \\
\hline $\begin{array}{l}\text { Said } \\
(2007)\end{array}$ & $\begin{array}{l}\text { Secondary } \\
\text { school } \\
\text { students, } \\
\text { Malaysia }\end{array}$ & $\begin{array}{l}\text { Sustainable } \\
\text { consumption } \\
\text { practices (SCP) }\end{array}$ & $\begin{array}{l}\text { Demographic variables, } \\
\text { Environmental } \\
\text { awareness, } \\
\text { environmental } \\
\text { knowledge, } \\
\text { environmental concern. }\end{array}$ & $\begin{array}{l}\text { - SCP had a significant } \\
\text { positive correlation with environmental } \\
\text { concern, environmental knowledge } \\
\text { - No significant difference } \\
\text { found between gender and } \\
\text { environmental knowledge, } \\
\text { environmental concern\& SCP }\end{array}$ \\
\hline $\begin{array}{l}\text { Oguz } \\
(2010)\end{array}$ & $\begin{array}{l}\text { University } \\
\text { Student, } \\
\text { Ankara, } \\
\text { Turkey }\end{array}$ & $\begin{array}{l}\text { Environmental } \\
\text { awareness, } \\
\text { Environmental } \\
\text { responsibility }\end{array}$ & $\begin{array}{ll}\text { Student } & \text { grades, } \\
\text { Environmental } & \\
\text { Knowledge } & \end{array}$ & $\begin{array}{l}\text { - Students taking courses on } \\
\text { environmental issues have lower } \\
\text { awareness and environmental } \\
\text { responsibility. } \\
\text { - Students' grades show no } \\
\text { significance. } \\
\text { Environmental knowledge } \\
\text { do not always influence awareness and } \\
\text { behavioral intentions }\end{array}$ \\
\hline $\begin{array}{l}\text { Altaher } \\
(2013)\end{array}$ & $\begin{array}{l}\text { Middle and } \\
\text { high schools } \\
\text { Saudi Arabia }\end{array}$ & $\begin{array}{l}\text { Perception of } \\
\text { different } \\
\text { environmental } \\
\text { issues and } \\
\text { environmental } \\
\text { attitude, behaviors }\end{array}$ & Age, Gender and grade. & $\begin{array}{l}\text { - Girls are } \\
\text { knowledgeable than boys. } \\
\text { - TV and internet are the } \\
\text { most important sources of information } \\
\text { about the environment. } \\
\text { - Awareness has a direct } \\
\text { relationship with level at school; } \\
\text { increases with increasing the grade at } \\
\text { school } \\
\text { - Students' attitude toward } \\
\text { protecting environment is not high } \\
\text { compared with their environmental } \\
\text { knowledge }\end{array}$ \\
\hline
\end{tabular}

AL and PL tools for imparting ESCB at primary level. 
Pollard (1991) mentions three contexts where children interact - home, classroom and playground with parents, teachers and peers respectively (Page 9); and gives his triadic representation of child's learning in social context (page 37). Given education's importance for enhancing decision making and behavioral capability for environmentally sustainable consumption, the classroom-teacher part of child's social context was considered for current study. Scope was limited to children studying in class III, IV and $\mathrm{V}$ at both government and private schools in urban localities.

Issues related to sustainable development are usually a much more pressing consideration for urban areas due to high population density (Alberti, 1996; Tripathi, 2013).

Table 2: Contrasting AL and PL modes of SL on important characteristics.

\begin{tabular}{|c|c|c|}
\hline Characteristics & Active Learning & Passive Learning \\
\hline $\begin{array}{l}\text { Retention, order } \\
\text { thinking, of } \\
\text { attention. }\end{array}$ & $\begin{array}{l}\text { Better retention, higher order } \\
\text { thinking, Student-oriented. }\end{array}$ & $\begin{array}{l}\text { Poorer retention, lower order } \\
\text { thinking, teacher oriented. }\end{array}$ \\
\hline Student attention & Greater & Lower level needed \\
\hline Collaboration & Encourages collaboration & Student works in isolation \\
\hline Emphasis area & Emphasis on process & Emphasis on memorization \\
\hline Source of information & $\begin{array}{l}\text { Multimedia programs, group } \\
\text { discussions, dramatic presentation, } \\
\text { simulations, tutoring. }\end{array}$ & $\begin{array}{l}\text { Newspaper, movie, radio program, } \\
\text { books, pamphlets. }\end{array}$ \\
\hline Goals & $\begin{array}{l}\text { Construct own knowledge about } \\
\text { subject areas } \\
\text { Discover relationship that exists } \\
\text { among items of information, } \\
\text { Organize subject matter } \\
\text { themselves. }\end{array}$ & $\begin{array}{l}\text { More information in less time } \\
\text { Information sources can be prepared } \\
\text { well in advance } \\
\text { Important concepts and content } \\
\text { identified a concrete, organized, and } \\
\text { meaningful manner. }\end{array}$ \\
\hline Examples & $\begin{array}{l}\text { Role playing, case studies, just in } \\
\text { time teaching, group project. }\end{array}$ & $\begin{array}{l}\text { Reading assignment, lecture, audio } \\
\text { visual. }\end{array}$ \\
\hline
\end{tabular}

\section{Objectives}

While many studies have looked at the effectiveness of SL tools for (mostly) higher education (see table6), few investigated primary school children and almost none looked at imparting ESCB to primary school children; therefore, present study aimed to dig deep into the primary school teachers' perception about SL tools for teaching ESCB. The current study had 3 objectives: tools

1) To identify AL \& PL tools from review of environmental studies text books for primary classes.

2) To identify AL \& PL tools from review of research studies pertaining to school level education.

3) To analyze qualitatively, perceptions of teachers about AL and PL with a view to gather insights on special constraints or opportunities faced by them. 


\section{Method}

Broad approach adopted is exploratory as very few studies looked at ESCB and none investigated SL tools for sustainable education of children. An extensive listing of $\mathrm{AL} \& \mathrm{PL}$ tools from environmental studies text books of class $\mathrm{I}$ to $\mathrm{V}$ for both government and private schools was done for objective 1. Similartools identification from research literature related to school level for objective 2 was undertaken. For the 3 rd objective, in-depth interviews of 50 school teachers for subject environmental studies (or it's equivalent) was done. Quota sampling was used which ensured a balanced distribution across moderating variables- school type (private vs government) and class (see table 3).All selected schools were from Bhiwadi (census representative town of Alwar district). A mapping process where individual tools were matched to a consciously identified classification schema given by Bonwell (1991) was completed. Final questionnaire followed Bonwell's schema. For analyzing gathered data quantitatively, frequency tables were used; for qualitative data similar cases were clustered as well as seen individually as required.

Table 3: Distribution of Environmental Studies teachers by school type and class.

\begin{tabular}{|l|l|l|}
\hline & \multicolumn{2}{|l|}{ School type } \\
\hline Class & Private & Government \\
\hline I & 7 & 2 \\
\hline II & 7 & 2 \\
\hline III & 8 & 2 \\
\hline IV & 9 & 3 \\
\hline V & 7 & 3 \\
\hline Total & 38 & 12 \\
\hline \multicolumn{3}{|l}{ Grand total $=\mathbf{5 0}$} \\
\hline
\end{tabular}

\section{Questionnaire}

For questionnaire development, Bonwell's (1991) classificatory schema of tools was placed against $16 \mathrm{ESCBs}$ from literature. It was also slightly modified to suit experience survey of exploratory approach to obtain teachers' insights, knowledge and experience regarding use of AL and PL tools. Respondents were given freedom for discussion to develop tentative explanation of what they shared. Questionnaire was thus only semistructured with open ended questions. The key question asked to respondents for each pair of 'SL tool-ESCB' was this: Based on your perception, which of the SL tools given here are appropriate for teaching (an identified) ESCB to children of your class. Respondents could choose more than one tool for specific ESCB item and were asked to express reasons for their favor or disfavor for specific tools. ESCB context was regularly reminded by reading out ESCB items and giving specific examples. In government schools where one teacher engages all primary classes, they were regularly reminded to answer for only one chosen class. Questionnaire was pretested with 15 environmental studies instructors from class I to $\mathrm{V}$. 


\section{Results and Findings}

\subsection{AL \& PL tools from text books and research papers.}

\section{Results}

Initial search to gather environmental studies text books from government and private schools revealed 2 facts: one, there were no text books for class I and II for government schools and for class I in private schools; two, teachers referred to a pre-decided and given framework in place of textbooks. A through scanning of text books to identify AL and PL tools showed both types of tools had been suggested for use (chapter end exercises and within chapter activities). Results summarizing all the tools have been provided in tables 4 and 5.

Table 4: Active tools found in private and government school text books

\begin{tabular}{|l|l|l|l|l|l|l|}
\hline \multicolumn{4}{|l|}{ School type } \\
\hline Active tools & \multicolumn{4}{|l|}{ Private } & \multicolumn{4}{l|}{} \\
\hline & Class 3 & Class 4 & Class 5 & Class 3 & Class 4 & Class 5 \\
\hline Projects & Yes & Yes & Yes & Yes & Yes & Yes \\
\hline Demonstration & Yes & Yes & Yes & Yes & Yes & Yes \\
\hline Writing & Yes & Yes & Yes & Yes & Yes & - \\
\hline Problem Solving & Yes & Yes & Yes & Yes & Yes & Yes \\
\hline Discussion & Yes & Yes & Yes & Yes & Yes & Yes \\
\hline Visual Based Instruction & Yes & Yes & Yes & - & - & - \\
\hline Field Work & - & Yes & - & - & - & - \\
\hline Cooperative learning & - & Yes & - & - & - & Yes \\
\hline
\end{tabular}

Table 5: Passive tools found in private and government school text books

\begin{tabular}{|l|l|l|l|l|l|l|}
\hline \multicolumn{7}{|l|}{ School type } \\
\hline Passive tools & \multicolumn{4}{l|}{ Private } & \multicolumn{2}{l|}{ Government } \\
\hline & Class 3 & Class 4 & Class 5 & Class 3 & Class 4 & Class 5 \\
\hline Narrate/Tell Stories & Yes & Yes & Yes & - & - & - \\
\hline Observation & Yes & Yes & Yes & Yes & Yes & Yes \\
\hline Visual based & - & - & - & Yes & Yes & Yes \\
\hline
\end{tabular}

Research which investigated AL and PL tools for school students were reviewed - a total of 7 such studies are given in table 6 . 
Table 6: Overview of research studies on AL and PL tools

\begin{tabular}{|c|c|c|c|c|}
\hline $\begin{array}{l}\text { Author } \\
\text { name }\end{array}$ & Year & $\begin{array}{l}\text { Students } \\
\text { studied }\end{array}$ & AL tools & $\begin{array}{l}\text { PL } \\
\text { tools }\end{array}$ \\
\hline Kitzerow P. & 1990 & $\begin{array}{l}\text { Upper middle } \\
\text { school }\end{array}$ & Group role plays & - \\
\hline Kyriacou.C. & 1992 & $\begin{array}{l}\text { Secondary } \\
\text { school }\end{array}$ & $\begin{array}{l}\text { Demonstration, problem solving, group discussion, } \\
\text { practical simulation, computer based activities, project }\end{array}$ & - \\
\hline Gaslow N.J & 1995 & $\begin{array}{l}11^{\text {th }} \text { grade } \\
\text { student }\end{array}$ & $\begin{array}{l}\text { Collaborative project, team problem solving, decision } \\
\text { making, role playing }\end{array}$ & - \\
\hline Ebert D. & 1997 & High school & $\begin{array}{l}\text { Concept map, daily quizzes, peer teaching, writing } \\
\text { activities }\end{array}$ & Lecture \\
\hline Niemi.H & 2002 & $\begin{array}{l}\text { Primary and } \\
\text { secondary }\end{array}$ & Co-operative learning & - \\
\hline Dengler $\mathrm{M}$ & 2008 & $\begin{array}{l}\text { Middle } \\
\text { school }\end{array}$ & Online discussion & - \\
\hline Edward S. & 2015 & $\begin{array}{l}\text { Middle } \\
\text { School }\end{array}$ & $\begin{array}{l}\text { Concept maps, problem-solving activities, creating } \\
\text { multimedia presentations, group discussion, lab } \\
\text { experiments, hands-on projects, games, building } \\
\text { models }\end{array}$ & - \\
\hline
\end{tabular}

\section{Findings}

A through look at the results in tables 4, 5, 6 lead to following observations:

1) AL tools are more frequently found than PL tools in both text books and research literature. In fact, some researchers chose only AL tools.

2) The set of AL or PL tools are not consistently prescribed in text books across classes even in the same type of school. This could have been intentionally designed to suit the age of the kids(for example, "small projects" has been given for III and above classes in private schools but not in class II). However, many other instances do not seem to be logical (for example, an activity like "writing" is deemed appropriate for classes II, III and IV but not for class V in private schools or "field trips" is found suitable for class II and IV only in private schools. Similarly, government schools text books prescribe "writing' for class III and IV but not for class V. Current study did not look into the reasons for such observations; it can be taken in later investigations.

3) Yet another interesting finding was that 3 tools-field trip, visual based instruction and storytelling/ narration were totally missing from government school text books.

4) Quite a few tools have not figured anywhere in text books but have been the subject of research investigations: role plays, practical simulation, computer based activities, Concept map, peer teaching, online discussion, creating multimedia presentations, lab experiments, games.

\subsection{Mapping SL tools to Bonwell's schema}

Classificatory schemas club AL tools by their characteristics (MacVaugh J., 2011; Wingfield S.S., 2010; Michel N., 2009; Prince M., 2004; Faust J.L, 1998; Bonwell C.C., 1991), one of the oldest being Bonwell's (1991) which has been referred to by multiple other researchers (Wingfield S.S, 2010; MichelN, 2009). It indeed has a very 
comprehensive coverage and enumerates 11 categories of AL tools where first five categories (pausing lecture, test and quizzes, demonstration, feedback lecture, guided lecture and responsive lecture) were further put under a broader classification "modified lecture". Here, all 11 categories were taken for finer level of study to map AL tools identified. The mapping output is shown in figure2.

Readers must note that Bonwell provided classificatory schema only for AL tools. The PL tools obtained from literature were checked for overlaps and a distinct list with following tools was used: lecture, visual instruction (posters, films, videotapes, TV), classroom presentation, computerized learning assignments, guest speakers, reading textbooks.

\section{Findings}

While the mapping process ensured referencing with an existing well known schema, it also pointed to important insights mentioned below:

1) None of the textbooks or research papers has recommended using the first 5 AL tools (all were different type of modified lecture) except demonstration.

2) Similarly, another tool that has not figured anywhere was computer based learning. Both these findings were very surprising given that Bonwell's schema was given way back in 1991 and more recent literature would be expected to include elements from old scripts.

3) All others have been recommended for use in both school types and by researchers focused on school level; only exception being visual based instruction (not present in government school text books).

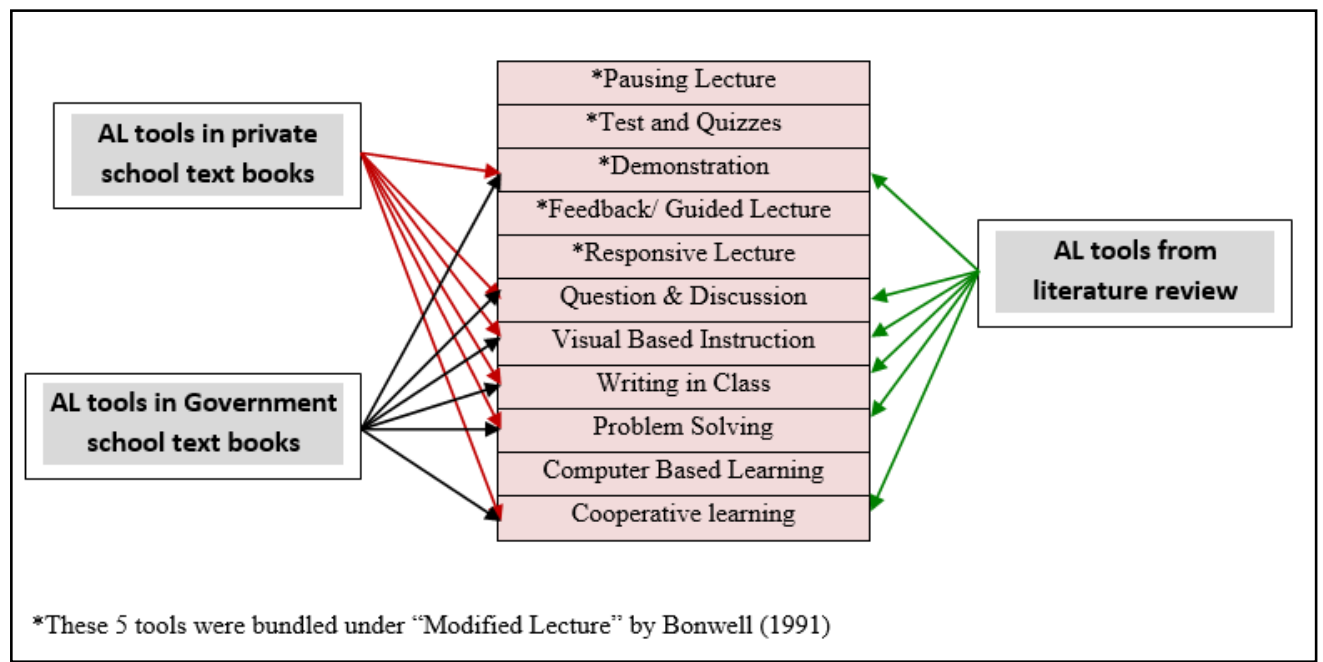

Figure 2: Mapping Active and Passive tools on Bonwell's (1991) classification

Reasons for exclusion of tools were not found in literature. However, part of this study attempted to throw more light by (i) accessing teachers' perceptions regarding AL and PL tools, looked into what teachers thought about them and (ii) exploring teachers' ideas/ opinions about opportunities and constraints faced. 


\subsection{Teachers Perceptions of SL tools Results for AL tools}

The questionnaire had 3 sections: 2ndsection recorded teacher's perceptions about and frequency with which they felt a particular ESCB could be taught using one or more AL tools; similarly, 3rd section recorded responses for PL tools. Since each of the 50 teachers could select more that one of $11 \mathrm{AL}$ tools or more than one form 5 PL tools as appropriate (16 behaviors were used) - maximum recordable frequency for each AL tool was $800[50$ participants* 16 ESCBs] and 250 for PL tools.

Recorded frequencies are shown in table 7 (AL tools for private schools), table 8 (AL tools for government schools), table 9 (PL tools for private schools) and table 10 (PL tools for government schools). The results in each of the 4 tables have been arranged in a descending order wrt the last column that shows total frequencies. Results from private schools showed that pausing lecture, visual based instruction and demonstration are the top choices for instructors; "problem solving" showed as an outlier and computer based learning, test\& quizzes and feedback lecture got least support. The pattern of top 3 choices and worst 5 choices from private schools was almost replicated by government school responses with relative positions changing only for 3 tools in bottom 5 rows.

Table 7: Selection frequency for AL tools in private schools

\begin{tabular}{|l|l|l|l|l|l|l|}
\hline & \multicolumn{3}{|l}{ Classes } \\
\hline ALtools & I & II & III & IV & V & Total \\
\hline Pausing Lecture & 82 & 92 & 70 & 92 & 95 & 431 \\
\hline Visual based instruction & 65 & 67 & 73 & 104 & 98 & 407 \\
\hline Demonstration & 58 & 71 & 66 & 76 & 43 & 314 \\
\hline Question and Discussion & 15 & 28 & 11 & 24 & 29 & 107 \\
\hline Cooperative learning & 10 & 17 & 11 & 20 & 17 & 75 \\
\hline writing in class & 5 & 25 & 3 & 12 & 10 & 55 \\
\hline Responsive Lecture & 3 & 17 & 6 & 6 & 20 & 52 \\
\hline Feedback lecture & 5 & 17 & 6 & 13 & 4 & 45 \\
\hline Test and Quizzes & 4 & 17 & 4 & 8 & 6 & 39 \\
\hline Computer based learning & 2 & 1 & 10 & 5 & 14 & 32 \\
\hline Problem solving & 0 & 0 & 1 & 1 & 0 & 2 \\
\hline Total responses & 249 & 352 & 261 & 361 & 336 & 1559 \\
\hline
\end{tabular}

Table 8: Selection frequency for AL tools in government schools

\begin{tabular}{|l|l|l|l|l|l|l|}
\hline \multicolumn{7}{|c|}{ Classes } \\
\hline AL tools & I & II & III & IV & V & Total \\
\hline Pausing Lecture & 20 & 18 & 17 & 29 & 25 & 109 \\
\hline Visual based instruction & 17 & 12 & 17 & 23 & 24 & 93 \\
\hline Demonstration & 11 & 5 & 9 & 11 & 12 & 48 \\
\hline Cooperative learning & 4 & 7 & 1 & 12 & 5 & 29 \\
\hline Question and Discussion & 10 & 0 & 0 & 3 & 0 & 13 \\
\hline Writing in class & 3 & 0 & 7 & 0 & 0 & 10 \\
\hline Test and Quizzes & 2 & 0 & 0 & 0 & 1 & 3 \\
\hline
\end{tabular}




\begin{tabular}{|l|l|l|l|l|l|l|} 
Feedback lecture & 0 & 0 & 0 & 0 & 2 & 2 \\
\hline Computer based leaning & 2 & 0 & 0 & 0 & 0 & 2 \\
\hline Responsive Lecture & 0 & 0 & 0 & 1 & 0 & 1 \\
\hline Problem solving & 0 & 0 & 0 & 0 & 0 & 0 \\
\hline Total & 69 & 42 & 51 & 79 & 69 & 310 \\
\hline
\end{tabular}

\section{Findings for AL tools}

Insights related to AL tools were structured around 3 aspects: first, interpretation of frequency summaries (tables7, 8)to identify patterns and consistencies in choice of tools if any; second, findings cum discussion based on both qualitative rational and/or opinions provided by teachers and third aspect adds appropriate literature evidences.

The findings have been given below:

1) The choice as well as relative positions as seen from last column of table 7,8 of the top three choices (namely pausing lecture, visual based instruction and demonstration) of teachers from both schools matched exactly, showing in turn the consistent and high preference for using them to teach sustainable consumption behavior. The actual statements given by teachers for pausing lecture express their favor/ disfavor and or rational wrt these 3 tools are given below:

Teacher 1: I use pausing lecture because when a teacher gives lecture with pauses, children are able to take notes and grasp better, therefore after some time they are able to make sense of what had been said. Additionally, comparing notes leads to increased recall of topics.

Teacher 2:I prefer pausing lecture as it helps me to emphasize important points during pauses. Children can not only complete and compare their notes but also use them for later referencing.

The positive points given by teachers for pausing lecture has been supported by May (1997) who found that active learning lecture format was related to significantly higher self-efficacy and skill development.

2) The uses of visual based instructions have been studied by multiple researchers and their findings eco similar beneficial outcomes as emphasized and voted by teachers. One of the statements to support use of visual based instruction given by a respondent is provided verbatim here:

Teacher 1:I use visual based instruction most frequently because I believe that students learn and retain more by seeing than listening, as they can correlate what they learn to with their own world.

Visuals have been supported as they can be used not only for any subject area (Brumo, 1982; Curtin, 2006) but also for diverse classes compositions (Curtis, 2001; Curtin, 2006). Learning is enhanced by pictures, cartoons, maps, graphs, charts, diagrams, videos, and other multimedia resources as they engage different senses, accommodate visual learners, and help reinforce key ideas by presenting information in alternative formats (Carrier, 2005, Rokni, 2013). Two evidences that came closest to present context were found: one 
by Curtin (2006), who mentioned that environment learners attached meaning and mental images to concepts through use of visual instructional materials; two, visuals were found helpful teaching students whose first language is not their mother language (Vaughn, 2003; Carrier, 2005). In case of Bhiwadi, from where respondents were chosen for investigation, mother tongue of most students was either Hindi or Rajasthani (the local dialect). This could be a very important reason why teachers chose visual based instruction as a preferred AL tool.

3) Demonstration as an AL tool was also one of the most favored tools. One of the teachers mentioned this:

Teacher 1: I use demonstration in class because it helps children to relate better to their existing world and develop thinking skills. This also helps in making classroom assessment easy.

While intuitively it sounds practical and justified, we looked also at what research investigations had to say -demonstration was found to be effective for schools (Aeison, 2007), apt for students from diverse and multicultural backgrounds (Kline,1995) who prefer hands-on-learning experience. This tool has also been supported for ease of assessment (Carrier, 2005; Curtin, 2006, Allison, 2007).

4) Computer assisted learning, points out Glasser (2009) would be contingent on educational infrastructure investments \& it's lack was reported by almost all teachers- government schools had absolutely no access to computers for primary level students (6 out of 11 government used computers for accounting purposes). Only 8 out of 73 private schools had computer lab with 10-20 computers.

Teachers in both schools reported following additional constraints: lack of training/expertise, confidence and maintenance at government teachers; lack of preparation time (also in Niemi, 2002), prescribed text book activities by all teachers.

\section{Results for PL tools}

Tables 9 and 10 give recorded frequencies for PL tools. Listening to lecture and visual media were teachers' top choices for both types of schools and computerized learning assignments figured at the bottom in both cases. The relative position of all tools across two types of schools was same.

Table 9: Selection frequency for PL tools in private schools

\begin{tabular}{|l|l|l|l|l|l|l|}
\hline & \multicolumn{4}{|l|}{ Classes } & \\
\hline PL tools & I & II & III & IV & V & Total \\
\hline Listening to lecture & 80 & 97 & 84 & 114 & 93 & 468 \\
\hline Visual media & 73 & 67 & 68 & 90 & 52 & 350 \\
\hline Classroom presentation & 27 & 33 & 28 & 33 & 27 & 148 \\
\hline Reading text books & 19 & 26 & 41 & 29 & 28 & 143 \\
\hline Computerized learning assignments & 11 & 20 & 19 & 26 & 41 & 117 \\
\hline Total & 210 & 243 & 240 & 292 & 241 & 1226 \\
\hline
\end{tabular}


Table 10:Selection frequency for PL tools in government schools

\begin{tabular}{|l|l|l|l|l|l|l|}
\hline & \multicolumn{3}{|l|}{ Classes } & \\
\hline PL tools & I & II & III & IV & V & Total \\
\hline Listening to lecture & 19 & 16 & 19 & 24 & 20 & 98 \\
\hline Visual media & 18 & 15 & 15 & 11 & 23 & 82 \\
\hline Classroom presentation & 4 & 8 & 4 & 11 & 10 & 37 \\
\hline Reading text books & 11 & 1 & 8 & 3 & 1 & 24 \\
\hline Computerized learning assignments & 8 & 3 & 0 & 10 & 3 & 24 \\
\hline Total & 60 & 43 & 46 & 59 & 57 & 265 \\
\hline
\end{tabular}

Findings for PL tools

Teachers have reported that listening to lecture is more or less like a default method, they are quite prepared \& open for it; also preparing is relatively easy as material is readily available from course and other books. Rodrigues, (2004) reports lectures seemed to be most effective at higher education level. The reasons for higher preference for visual media and low preference for computerized assignments are almost as reported under AL tools.

\section{Conclusions, limitations and future scope}

The overall perception of teachers provides their viewpoints regarding utility of SL tools for imparting sustainability education. The study also brings to light the ground realities faced by teachers in terms of opportunities and constraints (of infrastructure, timeenergy resources, text book support and syllabus). As a result, while faculties were aware of most SL tools, they were reluctant to use them in classes; which in turn suggests that teachers need more encouragement, resources and opportunities. Book need to be enriched with more SL tools to teach sustainability. Factoring these insights is expected to lead to development of a stronger framework where SL's potential for ESCB would materialize. Study's limitations include a small sample size and limited evaluation of tools based on teachers' perceptions (students' perceptions and/or learning outcomes can also be used to evaluate effectiveness of tools). Studies can also look at the reason for inconsistent prescription in text books. Last but not the least, higher level studies with empirical approach are recommended.

\section{References}

Alberti M (1996) Measuring Urban Sustainability. Environment impact assessment review 16: 381-424.

Allison B N, Rehm M L (2007) Effective teaching strategies for middle school learners in multicultural, multilingual classrooms. Middle School journal 39(2): 12-18.

Bandura A (1986) Social foundations of thought and action: A social cognitive theory. Englewood Cliffs, NJ: Prentice Hall

Bonwell C C, Eison JA (1991) Active learning:Creating excitement in the classroom. ASHE-Eric Higher Education Reort No 1. Washington DC,: George Washington University

Bruno A (1982) Hands-on wins hands down. Early Years 13(2): 60-67. 
Bryant C K, Hungerford H R (1977) An analysis of strategies for teaching environmental concepts and values clarification in kindergarten. Journal of Environmental Education, 9(1): 44-49.

Carrier K A (2005) Key issues for teaching English language learners in academic classrooms. Middle School Journal 37(2): 4-9.

Curtin E M (2006) Lessons on effective teaching from middle school ESL students. Middle School Journal 37(3): 38-45.

Curtis A, Bailey K M (2004) Picture your students talking: Using pictures in the language classroom. ESL Magazine 4(A): 10-11.

Dengler M (2008) Classroom Active Learning Complemented by an Online Discussion Forum to Teach Sustainability. Journal of Geography in Higher Education, 32(3):481-494

Ebert D M, Brewer C, Allred S (1997) Innovation in large lectures--teaching for active learning. Bioscience, 1997: 47(9).

Edward S (2015) Active learning in the middle grades. Middle School Journal, 26-32.

Engdahl I, Rabusicova M.(2010) Children's Voices about the State of the Earth and Sustainable Development.http://www.omep.org.gu.se/digitalAssets /1314/1314390 esd-congress-reportchild-interviews.pdf

Faust, J. L., \& Paulson, D. R. (1998). Active learning in the college classroom. Journal on Excellence in College Teaching, 9 (2), 3-24.

Glasgow, J. N., \& Bush, M. S. (1995). Promoting active learning and collaborative writing through a marketing project. The English Journal, 84(8), 32-37.

Glasser H (2009) Minding the Gap. In: Wals A E J (ed) Social learning towards a sustainable world: principles, perspectives, and praxis. Wageningen Academic Publishers, Netherlands, p 35-62.

Hanss D, Bohm G (2012) Sustainability seen from the perspective of consumers. International Journal of Consumer Studies 36: 678-687.

Hartley E.L. "Passive learning from television," Proceedings of World association for public opinion research,Amsterdam,1969,June 1-4.

Kitzerow P (1990) Active learning in the classroom: The use of Group plays. Teaching Sociology 18(2): 223-225.

Kline L W (1995) A baker's dozen: Effective instructional strategies. In: Cole R W (ed) Educating everybody's children: Diverse teaching strategies for diverse learners, Alexandria, VA: Association for Supervision and Curriculum Development, pp. 21-43.

Kyriacou C (1992) Active Learning in Secondary School Mathematics. British Educational Research Journal 18(3):309-318

Light P, Littleton K (2000) Peer interaction and learning: perspectives and starting points. In: Social Processes in children's learning, Cambridge University Press, UK, pp 1-13

Luckner, J. L., \& Nadler, R. S. (1997). Processing the experience: Strategies to enhance and generalize learning. Kendall/Hunt Publishing Company, 4050 Westmark Drive, Dubuque, IA 52002.

MacVaugh J, Norton M (2012). Introducing sustainability into business education contexts using active learning. International Journal of Sustainability in Higher Education. 13(1): 72-87

Mahmood M. A., Tariq M., Javed S., "Strategies for active learning: an alternative to passive learning," Academic Research International, 2011, 1(3): 193-198.

Mansuroglu S, Karaguzel O, Atik M, Kinikli P (2009) Determining environmental sensitivity of inhabitants of Antalya City, Turkey. Journal of Food,Agriculture \& Environment 7(3):961-969.

May D E, Brewer C, Allred S (1997) Inovvation in large lectures- teaching for active learning. Bioscience 47, 9

McCarthy J P, Anderson L (2000) Active Learning Techniques Versus Traditional Teaching Styles: Two Experimets from Hisory and Political Science. Innovative Higher Education 24(4):279-294.

Michel N, James J. (2009) Active Versus Passive Teaching Styles: An Empirical Study of Student Learning Outcomes. Human Resource Development Quarterly 20(4): 397-418.

Monroe M C. (2003) Two Avenues for Encouraging Conservation Behaviors. Human Ecology Review 10(2): $113-125$.

Muderrisoglu H, Altanlar A (2011) Attitudes and behaviors of undergraduate students toward environmental issues. International Journal of Environmental Science and Technology 8 (1): 159-168.

Niemi H (2002) Active learning - a cultural change needed in teacher education and schools. Teaching and Teacher Education 18 (2002) 763-780

Oguz D, Cakci I, Kavas S (2010) Environmental awareness of University Students in Ankara, Turkey. African Journal of Agricultural Research 5(19): 2629-2636. 
Omelicheva M Y, Avdeyeva O (2008) Teaching with lecture or debate? Testing the effectiveness of traditional versus active learning methods of instruction. Political Science and sciences 41(3): 603607

Pezzoli, K (1997) Sustainable development: A trans disciplinary overview of the literature. Journal of Environmental Planning and management 40: 549-574.

Phipps M, Ozanne L K, Luchs M G, Subrahmanyan S, Kapitan S, Catlin J R, Gau R, Naylor R W, Rose R L, Simpson B, Weaver $\mathrm{T}$ (2013) Understanding the Inherent Complexity of Sustainable Consumption: A Social Cognitive Framework. Journal of Business Research 66, 1-8

Pollard, A. (2001). The social world of children's learning. A\&C Black.

Prince M (2004) Does Active Learning Work? A Review of the Research. Journal of Engineering Education, 93(3):223-231

Rodrigues C A (2004) The importance level of ten teaching/learning techniques as rated by university business students and instructor. Journal of Management Development 23(2): 169-182.

Said A M, Ahmadun F R, Paim L H, Masud J (2003) Environmental concerns, knowledge and practices gap among Malaysian teachers. International Journal of Sustainability in Higher Education 4(4) :305 - 313.

Said A M, Yahaya N, Ahmadun F R (2007) Environmental comprehension and participation of Malaysian secondary school students. Environmental Education Research 13(1): 17-31

Schrader U., Thogersen J. (2011) Putting sustainable consumption into practice. Journal of consumer policy 34 :38.

Steg L, Vlek C (2009) Encouraging pro-environmental behavior: An integrative review and research agenda. Journal of environmental psychology 29:309-317.

Strong C (1998) The impact of environmental education on children's knowledge and awareness of environmental concerns. Marketing Intelligence and Planning 16(6): 349-355.

Sudarmadi S, Suzuki S, Kawada T, Tugaswati A T R I (2001) A survey of perception , knowledge , awareness, and attitude in regard to environmental problems in a sample of two different social groups in Jakarta ,Indonesia. Environment, Development and Sustainability 3: 169-183.

Tanner C, Kast S W (2003) Promoting sustainable consumption: Determinants of green purchases by Swiss Consumer. Psychology \& Marketing 20(10): 883-902.

Thogersen J, Olander F (2002) Human Values and the emergence of a sustainable consumption pattern: A panel study. Journal of economic psychology 23: 605-630.

Tripathi S (2013), “An overview of India's urbanization, urban economic growth and urban equity", available at: http://mpra.ub.uni-muenchen.de/45537/

Vaughn S, Bos C S, Sc Schümm J S (2003) Teaching exceptional, diverse, and at-risk students in the general education classroom (3rd ed.), Boston: Allyn Sc Bacon.

Wals A E J (2007) Learning in a Changing World and Changing in a Learning World: Reflexively fumbling towards sustainability. Southern African Journal of Environmental Education 24: 35-45.

Wals A. E. J. "Social learning towards a sustainable world : principles, perspectives, and praxis" Wageningen Academic Publishers, 2007,12(4):624-627.

Wilke R. R. "The Effect of Active Learning on Student Characteristics in a Human Physiology Course for Non majors," Advances in Physiology Education, 2003, 27(4): 207-223.

Wingfield S S, Black G S(2005) Active Versus Passive Course Designs: The Impact on Student Outcomes. Journal of Education for Business, 81(2):119-123

54. Wong K K (2003) The Environmental Awareness of University Students in Beijing, China. Journal of Contemporary China 12(36): 519-536 